\title{
KUALITAS MANAJEMEN KEUANGAN USAHA MIKRO KECIL MENENGAH (UMKM) \\ (STUDI KASUS PADA DISTRIBUTION STORE (DISTRO) DI KOTA MEDAN) \\ Oleh: \\ Diana Hasyim
}

\begin{abstract}
Abstrak
Tujuan dalam penelitian ini adalah untuk menunjukkan dan menjelaskan keadaan manajemen Dkeuangan Usaha Mikro Kecil Menengah (UMKM) Distribution Store (Distro) berdasarkan teori manajemen keuangan khususnya dalam hal pengaturan keuangan dan fungsi manajemen keuangan. Penarikan sampel dilakukan dengan metode area sampling. Sumber data dalam penelitian ini adalah data primer yang diperoleh dari kuisioner terstruktur dan kuisioner terbuka yang dibagikan kepada pelaku usaha distro. Pada kuisioner terstruktur jumlah responden adalah 55 distro dan pada kuisioner terbuka jumlah responden sebanyak 25 distro. Metode yang digunakan dalam pengolahan data adalah metode statistik deskriptif untuk menjelaskan mean, range, minimum, maximum dan sebagainya. Dari hasil statistik diperoleh sebesar 52\% distro memiliki pemasukan lain selain usaha distro. Kemudian $51 \%$ pengusaha distro telah memaksimalkan menggunakan dana untuk keperluan perusahaan. Dari segi pembiayaan, sebesar 64\% distro menggunakan hutang. Dari segi tabungan, sebesar $78 \%$ distro memiliki tabungan di bank. Akan tetapi, sebesar $55 \%$ distro yang memisahkan tabungan pribadi dengan tabungan perusahaan. Sehingga dapat disimpulkan bahwa sebesar $92,73 \%$ distro telah memiliki predikat pengaturan keuangan yang baik. Dari segi keuntungan, distro memiliki keuntungan atau laba bersih ratarata 5\% dari total investasinya setiap bulan. Dari segi DER (Debt Equty Ratio), rata-rata distro memiliki rasio DER 0,8:1. WCTA (working capital to total asset) atau aktiva lancar yang dimiliki distro rata-rata sebesar 33,98\% dari total asset yang dimiliki.
\end{abstract}

Kata Kunci : Pengaturan Keuangan, ROI (Return on Investment), DER (Debt Equity Ratio) dan WCTA (Working Capital to Total Assets).

\section{A. Pendahuluan}

Program pemerintah dalam menggalakkan Usaha Mikro Kecil Menengah (UMKM) menunjukkan perkembangan positif. Dari sisi jumlah, pada tahun 2009 jumlah UMKM berkisar 52,8 juta unit. Pada tahun 2012, jumlah UMKM meningkat menjadi 55,4 juta unit. Dalam kaitannya dengan penyerapan tenaga kerja, rata-rata UMKM dapat menyerap 3-5 orang pekerja. Sehingga

\footnotetext{
* Dosen Jurusan Manajemen FE Unimed
} 
dengan penambahan sekitar 3 (tiga) juta unit dalam tiga tahun tersebut (2009-2012), jumlah tenaga kerja yang terserap bertambah 15 (lima belas) juta orang.

Penelitian yang dilakukan oleh Bank Indonesia dan PUSLIT FE USU (2008), sektor UMKM di Sumatera Utara umumnya bergerak dibidang perdagangan (66,46\%). Sisanya, sebesar $15,58 \%$ di sektor jasa, sebesar $12,20 \%$ sektor perindustrian, dan sebesar $6,60 \%$ sector lainnya, meliputi pertanian, pertambangan \& penggalian, listrik, gas, air, keuangan, jasa perusahaan, pengangkutan dan komunikasi.

Permasalahan yang terjadi pada keseluruhan UMKM di atas, umumnya berkaitan dengan ekspansi usaha atau sebagai usaha yang hanya mampu bertahan hidup. Penelitian PUSLIT FE USU dan BI menunjukkan bahwa kebutuhan modal kerja merupakan salah satu faktor kendala pengembangan UMKM. Penelitian ini sejalan dengan kajian Mambula (2002), yang menyatakan bahwa sebanyak $72 \%$ pengusaha kecil memiliki hambatan dalam pengembangan usaha dikarenakan kurangnya pembiayaan. Berdasarkan catatan Bank Indonesia (www.bi.go.id), jumlah kebutuhan kredit modal kerja UMKM mengalami peningkatan setiap tahunnya. Pada tahun 2011, jumlah kredit modal kerja UMKM yang tercatat sebesar Rp. 375.295,9 milyar. Jumlah ini meningkat pada tahun 2012 menjadi sebesar Rp. 381.907,1 milyar, dan menjadi sebesar Rp. 443.051,1 milyar pada tahun 2013.

Catatan ini sejalan dengan dengan penelitian Syarif (2010) berjudul "Proporsi Penyaluran Dana Untuk UMKM" menyimpulkan bahwa kenyataan menunjukan bahwa permintaan kredit (demand of credit) dari kalangan UMKM relatif cukup besar. Tetapi sebagian besar kebutuhan kredit tersebut dipenuhi oleh para pelepas uang dengan bunga yang relatif tinggi. Dampak dari biaya modal yang tinggi ini terlihat dari non-performing loan (kredit macet) sektor ini. Pada April 2013, Bank Indonesia mencatat bahwa kredit macet sektor UMKM mencapai Rp. 4,310 milyar. Disisi yang lain, terlihat bahwa kecenderungan kredit yang disalurkan oleh lembaga perkreditan formal untuk UMKM masih kurang dari $14 \%$.

Faktor kendala lainnya dalam pengembangan UMKM berupa informasi keuangan. Sebesar 77,5\% UMKM tidak memiliki laporan keuangan dan sisanya, sebesar 22,5\%, memiliki laporan keuangan. Dari sisi jenis laporan keuangan yang dimiliki UMKM, sebesar 23,2\% menyusun neraca, sebesar 34,3\% menyusun laba rugi, menyusun arus kas sebesar 34,4\%, dan persediaan barang sebesar 30,9\%. Walaupun relatif jauh dari yang 
diharapkan, sebesar 53\% hanya memiliki catatan mengenai uang masuk dan keluar.

$\begin{array}{cccr} & \text { Profesionalisme pengelolaan keuangan juga menjadi } \\ \text { kendala dalam pengembangan } & \text { UMKM. } & \text { Dalam }\end{array}$ operasionalisasinya, Banyak pelaku UMKM tidak melakukan pemisahan antara uang pribadi dan uang perusahaan, sehingga operasionalisasi keuangan usaha menjadi tumpang tindih. Berdasarkan penelitian PUSLIT FE USU dan BI (2008), sebesar $57,93 \%$ pelaku UMKM di Sumatera Utara memiliki 1 (satu) rekening, sebesar $24,83 \%$ memiliki 2 (dua) rekening, dan hanya sebesar 17,24\% memiliki 3 (tiga) rekening.

Distribution Store (Distro) atau Distribution Outlet merupakan salah satu UMKM yang bergerak di bidang perdagangan, dengan fokus bisnis pada usaha penjualan pakaian dan aksesoris yang dititipkan oleh produsen pakaian atau produksi sendiri. UMKM yang bergerak dalam usaha ini membedakan usahanya dengan usaha lain yang sejenis melalui pembatasan produk, yaitu produk yang dihasilkan tidak diproduksi secara massal dengan tujuan untuk mempertahankan ekslusivismenya.

Pada tahun 2007, diperkirakan terdapat sekitar 700 unit usaha distro di Indonesia. Khususnya di Medan, jumlah usaha ini sekitar 100-an unit pada tahun 2004, dimana jumlah tersebut diperkirakan 4 (empat) kali lebih banyak dari tahun sebelumnya. Namun saat ini, jumlah usaha ini jauh berkurang.

Faktor penyebab kemunduran UMKM ini di kota Medan diduga tidak terlepas dari permasalahan yang dihadapi oleh UMKM secara keseluruhan, yaitu mengenai pendanaan investasi, non performing loan, dan pengelolaan aktiva tetap dan aktiva lancar tanpa adanya pencatatan atau tidak memiliki laporan keuangan sebagai alat pengambilan keputusan.

Dalam memecahkan masalah kemunduran suatu usaha, secara umum dapat dianalisis melalui 2 (dua) aspek, yaitu finansial dan non-finansial.

Aspek non-finansial berupa pengukuran kegiatan pemasaran, manajemen SDM, riset pasar, pendidikan pengelola, peramalan permintaan, dan lainnya (Temtime dan Pansiri, 2004). Sedangkan aspek finansial dapat diukur melalui analisis investasi, modal kerja, kredit usaha, dan segala bentuk manajemen keuangan lainnya.

Menurut Husnan (2010:6), "Manajemen keuangan adalah pengaturan kegiatan keuangan dalam suatu organisasi. Manajemen keuangan menyangkut kegiatan perencanaan, analisis dan pengendalian kegiatan keuangan". Sedangkan menurut Horne dan Wachowicz JR, "Manajemen keuangan berkaitan erat dengan 
perolehan pendanaan dan manajemen aktiva dengan beberapa tujuan umum sebagai latar belakangnya". Didasarkan pernyataan Horne dan Wachowicz JR, Sugiono (2009:5) membagi Manajemen Keuangan kedalam empat fungsi: (1). Keputusan pembiayaan (financing decision), (2). Keputusan Investasi (Investment Decision), (3). Kebijakan Dividen (Dividend Policy), dan (4). Pengelolaan Aktiva Lancar

Mengacu kepada definisi dan fungsi Manajemen Keuangan, penelitian ini bertujuan untuk menunjukkan dan menjelaskan kualitas manajemen keuangan UMKM usaha distro berdasarkan teori manajemen keuangan khususnya dalam hal pengelolaan keuangan dan fungsi manajemen keuangan, yaitu keputusan pembiayaan, keputusan investasi, dan pengelolaan aktiva lancar.

\section{B. Metode Penelitian}

Penelitian ini dilakukan di kota Medan, Provinsi Sumatera Utara, yang terdiri dari sepanjang Jl. Halat, Jl. Dr. Mansyur, J1. Jamin ginting Padang bulan, Jl. Setia budi, dan kawasan Ring road.

Populasi dalam penelitian ini adalah seluruh distro yang terdapat di jalan Dr. Mansyur, jalan Halat, jalan Setia Budi, kawasan Ring road, dan kawasan Padang Bulan, khususnya kecamatan Medan Baru. Sedangkan sampel penelitian adalah keseluruhan populasi, dikarenakan sampel ditentukan berdasarkan homogenitas distro, yaitu distro untuk kalangan menengah. Total sample yang diperoleh berdasarkan ketetapan tersebut lebih kurang 60 sample dan metode pemilihan sampel menggunakan metode area sampling.

Jenis penelitian ini adalah penelitian deskriptif. Data yang diperoleh dari penelitian ini berupa data rasio dan ordinal dengan sumber data berupa data primer dengan menggunakan beberapa metode pengumpulan data original, yaitu :

1. Wawancara : antara peneliti dan narasumber yang diarahkan oleh pewawancara untuk tujuan memperoleh informasi yang relevan.

2. Angket terbuka : angket yang disajikan dalam bentuk sedemikian rupa sehingga responden dapat memberikan isian sesuai dengan kehendak dan keadaan yang sebenarnya.

3. Angket tertutup : angket yang disajikan dalam bentuk sedemikian rupa sehingga responden dapat memberikan isian sesuai dengan pengukuran penelitian yang dibatasi dengan skor. Angket tersebut berisi pertanyaan yang disebarkan kepada responden. Dari pertanyaan atau pernyataan itu 
kemudian ditentukan option-option atau skala-skala yang dipilih dan juga skor untuk setiap pernyataan tersebut, jenis skala yang digunakan untuk mengukur pernyataan-pernyataan dalam angket adalah skala Likert. Skor jawaban angket yang digunakan dalam penelitian ini adalah:

Tabel Pedoman Pemberian Skor

\begin{tabular}{|l|l|}
\hline Pernyataan & Skor \\
\hline Ya & 3 \\
\hline Ragu-ragu & 2 \\
\hline Tidak & 1 \\
\hline \multicolumn{2}{|c|}{ Skor yang dinyatakan dengan bilangan merupakan }
\end{tabular}

langkah awal dari proses analisis. Kemudian skor tersebut akan diolah sehingga dapat menunjukkan pernyataan, keadaan, ukuran, dan kualitas sehingga dapat menghasilkan sebuah predikat "Baik" atau "Kurang Baik".

Analisis data dalam penelitian ini dilakukan dengan cara :

1. Analisis $\mathrm{N}$ untuk mengetaui jumlah data yang terkumpul yang akan dianalisis. Analisis $\mathrm{N}$ menunjukkan jumlah responden yang diukur dan yang missing (jumlah responden yang hilang atau datanya tidak lengkap).

2. Analisis Mean digunakan untuk mengetahui hasil rata-rata masing-masing variabel pada tiap sampel, yang diperoleh dari penjumlahan seluruh ukuran (data) dibagi dengan jumlah ukuran.

3. Median menghasilkan pengurutan data dan kemudian otomatis menghasilkan nilai tengah. Nilai tengah atau median ini menunjukkan bahwa 50\% sampel berada diatas median ratio variabel dan 50\% dibawah median variabel.

4. Standard Deviation menunjukkan penyebaran rata-rata dari sampel, dengan cara membandingkan range minimum dan maximum. Bila standar deviasi besar berarti data yang digunakan sebaran/variabilitasnya tinggi. Bila standar deviasi kecil, maka data yang digunakan mengelompok di seputar nilai rata-ratanya dan penyimpangan kecil.

5. Range menunjukkan jarak rasio variabel tertinggi dan terendah yang merupakan selisih antara nilai terbesar dan nilai terkecil dari suatu himpunan data.

6. Rasio Kurtosis dan Rasio Skewness, untuk menunjukkan kenormalan distribusi data. Distribusi normal apabila terletak antara -2 sampai +2 . 


\section{Hasil dan Pembahasan}

\section{Analisis Deskriptif (Karakteristik Pelaku Distro)}

Responden dalam penelitian ini adalah para pelaku usaha distro atau owner dari distro. Penyebaran ini dilakukan pada 60 distro yang diharapkan mampu mengisi secara keseluruhan pertanyaan. Akan tetapi hanya 55 yang dapat mengembalikan dan menjawab pertanyaan yang diberikan. Karakteristik responden dilihat dari jenis kelamin, usia, dan pendidikan terakhir.

\section{a. Jenis Kelamin}

Sebagian besar distro merupakan usaha yang dijalankan oleh sebuah keluarga. Sebagian besar yang menjalankan usaha distro adalah pria (kepala keluarga) yaitu sekitar 50 distro (91\%) dan sisanya 5 distro (9\%) merupakan wanita.

\section{b. Usia}

Berdasarkan tabel terlihat bahwa sebanyak 8 distro (14\%) pemiliknya berusia 17-29 tahun, dan 30 orang (55\%) berusia 30 45 tahun, kemudian usia 46 - 60 berjumlah 17 orang (31\%). Wanita pelaku usaha distro dua orang terletak pada usia $30-45$ dan dua orang pada usia 46 - 60 dan satu orang pada usia 17 -29 Tahun.

\section{c. Pendidikan Terakhir}

Dari segi pendidikan, proporsi responden yang tamat perguruan tinggi sebanyak 49 distro (89\%) dan selebihnya merupakan tamat SMA sebanyak 6 distro (11\%). Wanita yang lulus SMA ada sebanyak tiga orang dan lulus perguruan tinggi sebanyak dua orang.

\section{Analisis Deskriptif Pengaturan Keuangan}

\section{a. Analisis Item pertanyaan}

Setiap item pertanyaan yang diajukan, diharapkan mampu untuk menilai manajemen keuangan distro. Dari item pertanyaan yang dijawab oleh responden, bahwa pemilik distro umumnya memiliki laporan keuangan berupa arus kas masuk dan arus kas keluar. Dengan laporan tersebut, sebagian pemilik distro dapat memprediksi pengeluaran dan pemasukan untuk bulan selanjutnya. Kemudian sebagian besar pemilik distro juga memiliki pemasukan yang lebih besar dari pada pengeluaran. Selain itu lebih dari 52\% pemilik distro memiliki pemasukan lain selain usaha distro, baik itu usaha pabrik konveksi maupun pengadaan pakaian secara massal. Sebesar $43 \%$ lebih pemilik distro mampu membedakan uang perusahaan dengan uang pribadi karena pemilik distro telah menerapkan penggajian diri sendiri. Menurut pemilik distro $(51 \%$ lebih) dana telah maksimal digunakan untuk keperluan perusahaan. 
Dari segi pembiayaan usaha, 64\% lebih distro menggunakan hutang. Hutang tersebut sebagian besar berasal dari perbankan. Perbankan berperan penting dalam pembiayaan distro. Hanya sebagian kecil distro $(7,27 \%)$ yang kekurangan modal usaha.

Dari segi tabungan, $78 \%$ lebih distro memiliki tabungan di bank. Dari proporsi tersebut, sebesar 55\% memisahkan tabungan pribadi dengan tabungan perusahaan. Namun, sebesar $34 \%$ tidak pernah sama sekali mengambil uang perusahaan untuk keperluan pribadi.

Dari segi evaluasi keuangan, sebesar $47 \%$ pelaku distro melakukan evaluasi laporan keuangan, minimal satu tahun. Dan dengan pertanyaan "sudahkah laporan keuangan anda cukup baik?". Sebesar 58\% menjawab ragu-ragu, dan sebesar $40 \%$ menjawab cukup baik. Kemudian sebesar $50 \%$ pemilik distro rutin melakukan pemeriksaan laporan keuangan yang dilakukan oleh pegawainya.

Selain itu, sebesar $65 \%$ pemilik distro ragu-ragu dengan ketepatan penggunaan uang perusahaan untuk pembelanjaan yang dilakukan. Tidak tepatnya dalam penggunaan uang perusahaan menyebabkan banyaknya persediaan barang yang menganggur sehingga perubahan trend fashion menyebabkan barang tertentu tidak terjual. Dan sebesar $65 \%$ pemilik distro terkadang mengalami penyimpangan uang masuk dan uang keluar.

Laporan keuangan yang dibuat oleh pemilik distro menunjukkan kondisi keuangan dan evaluasi dari usaha yang dilakukan. Sebesar 58\% lebih pemilik distro menggunakan laporan keuangan untuk informasi kondisi keuangan. Dan sebesar 74\% lebih pemilik distro menggunakan laporan keuangan untuk evaluasi dari kegiatan usaha.

\section{b. Analisis Indikator}

Analisis indicator ini menjelaskan kualitas manajemen keuangan UMKM distro yang dapat disimpulkan bahwa UMKM distro memiliki laporan keuangan namun hanya terkadang saja dilakukan evaluasi terhadap laporan keuangan yang telah dibuat. Sedangkan indikator pelaporan keuangan dijadikan dasar untuk mengetahui barang masuk dan keluar serta untuk mengetahui kondisi usaha.

\section{c. Analisis Total Skor}

Data yang diambil dari kuesioner merupakan data ordinal. Data ordinal ini memiliki tingkatan "1-3". Data ordinal yang didapat dari setiap distro ini kemudian dijumlahkan sesuai dengan item pertanyaan. Hasil penjumlahan ini menghasilkan total skor dari setiap distro yang menjadi responden. 


\section{d. Analisis Deskriptif Fungsi Keuangan.}

Untuk indikator fungsi keuangan, yaitu ROI, DER, dan Working Capital to Total Asset (WATC).

1. ROI adalah laba bersih dalam pengukuran ROI diukur dengan menggunakan persamaan :

$\mathrm{NP}=\mathrm{O}-(1$ - ER $\times \mathrm{O})-\mathrm{C}$.

$\mathrm{NP}=$ Net profit (laba bersih rata-rata per-bulan)

$\mathrm{O}=$ Omset per bulan

ER = harapan keuntungan (persentase) tiap barang yang terjual $\mathrm{C}$ = biaya usaha.

2. DER adalah untuk melihat keadaan hutang pada sampel responden, DER dihitung hanya pada distro yang memiliki hutang pada perbankan.

3. WCTA (Working Capital to Total Asset) merupakan perbandingan antara modal kerja bersih dibanding dengan total aktiva. Modal kerja bersih pada distro dihitung dengan kas ditambah dengan persediaan item barang dikurang dengan hutang lancar.

\section{Analisis dan Pembahasan}

Pada penelitian kualitatif menunjukkan bahwa sebagian kecil distro yang tidak memiliki laporan keuangan hal ini ditunjukkan pada skor keseluruhan item pertanyaan. Skor ini mengacu pada baik tidaknya kualitas manajemen keuangan yang didasarkan pada predikat. Predikat tersebut diukur dengan rentang 23 sampai 46 menunjukkan kualitas manajemen keuangan kurang baik sedangkan 47 sampai dengan 69 menunjukkan kualitas manajemen keuangan distro baik. Pada penelitian ini didapat hanya sebagian kecil yang memiliki nilai di bawah 47. Yaitu sebanyak 4 distro dari 55 sampel $(7,27 \%)$. Selain itu, dari rata-rata juga menunjukkan skor item sebesa 54,836 dengan standard error mean sebesar 0,858 . Skor 54,836 tersebut terletak pada predikat manajemen keuangan yang baik. Manajemen keuangan yang baik dapat mengurangi pengeluaran yang kurang diperlukan perusahaan, dimana dana yang tertanam pada perusahaan dapat dimaksimalkan untuk kemajuan usaha.

Pada item pertanyaan, tersebut sebesar $63 \%$ lebih distro tidak terlepas dari hutang perbankan khususnya. Hutang tersebut sebagian bahkan lebih besar daripada modal sendiri. Nilai maximum pada DER menunjukkan bahwa rasio hutang dibanding modal sendiri senilai $2: 1$. Penggunaan hutang tersebut lebih besar dua kali dibanding dengan modal sendiri. Sedangkan rasio DER minimum sebesar $27,27 \%$ atau $0,27: 1$. Kemudian rata-rata rasio 
DER pada distro sebesar $0,8: 1$. Ini menunjukkan bahwa rata-rata penggunaan hutang lebih kecil daripada modal sendiri.

Pada item pertanyaan juga disebutkan sebagian besar distro juga memiliki pemasukan lebih besar dari pengeluaran distro.

Pada nilai ROI, sebagian besar distro berada pada 5,22\%. Nilai ROI ini lebih besar dari rata-rata kredit perbankan terhadap UMKM yang diasumsikan sebagai biaya modal distro (bunga kredit perbankan), rata-rata sebesar 0,9488 . Nilai ROI yang lebih besar dapat diartikan bahwa UMKM distro menguntungkan. Namun tidak semua distro memiliki ROI yang lebih besar dari bunga kredit perbankan. Terdapat juga distro yang memiliki ROI lebih kecil dari bunga kredit perbankan yaitu sebesar 0,89. Nilai tersebut menunjukkan terdapat juga distro yang merugi dalam menjalankan usahanya.

Dari sisi modal kerja untuk memenuhi permintaan, menunjukkan modal kerja yang dimiliki distro rata-rata 33,98\% dari total aktiva yang dimilikinya. Modal kerja minimum sebesar $13,2 \%$ dan maximum $71,67 \%$.

Total investasi pada distro beragam. Beberapa distro memiliki investasi yang cukup besar. Hal ini disebabkan satu owner memiliki beberapa distro. Secara keseluruhan rata-rata investasi yang dimiliki distro sebesar Rp 279.600.000,00.

\section{E. Kesimpulan}

Berdasarkan pada hasil penelitian yang diperoleh, beberapa kesimpulan yang dapat dirumuskan, sebagai berikut :

1. Karakteristik pelaku usaha distro sebagian besar $(90,9 \%)$ berjenis kelamin laki-laki dan dari segi usia berusia $30-45$ $(54,5 \%)$ dan 46-60 (30,9\%). Kemudian dari tingkat pendidikan sebagian besar $(89 \%)$ lulus perguruan tinggi.

2. Dari segi kualitatif sebagian besar distro telah menyusun dan menggunakan laporan keuangan untuk mengetahui kondisi keuangan dan persediaan mereka serta untuk pengambilan keputusan. Namun pada indikator pengendalian keuangan, pelaku distro umumnya sulit untuk tidak menggunakan uang perusahaan menjadi uang pribadi.

3. Dan dari segi kuantitatif pelaku usaha distro umumnya membutuhkan hutang untuk menjalankan usahanya. Sebagian besar pinjaman itu berasal dari perbankan. Pelaku distro juga memiliki keuntungan yang lebih besar dari biaya modal yang dihadapakan kepada mereka. 


\section{Daftar Pustaka}

Arief, Yani, dan Rienna. 2012. "Strategi Pengembangan Usaha Kecil Menengah Sektor Industri Pengolahan". Jurnal Bidang Industri, Vol. 13, No. 1.

Arikunto. 2009. "Manajemen Penelitian". Jakarta. Rineka Cipta

Badan Kajian Koperasi dan UKM. 2006. "Kajian Faktor-faktor yang Memperngaruhi Perkembangan Usaha UKM di Propinsi Sumatera Utara".. Jurnal Pengkajian Koperasi dan UKM, No. 23.

Bayu dan Sulistiyo. 2011. "Model Pembiayaan Usaha Kecil dan Menengah Pemasok ke Peritel Besar". Jurnal Bidang Ekonomi, Vol. 10, No. 1 Hafsah, Jafar. 2004. "Upaya Pengembangan Usaha Kecil dan Menengah (UKM)". Infokop, No. 25, Tahun XX.

Horne, Van dan Wachowicz. JR. 2007. "Prinsip-prinsip Manajemen Keuangan". Jakarta. Salemba Empat.

Husnan, Suad. 2010. "Manajemen Keuangan : Prinsip dan Penerapan Jangka Panjang". Yogyakarta. BPFE.

Husnan, Suad. 2010. "Manajemen Keuangan : Prinsip dan Penerapan Jangka Pendek". Yogyakarta. BPFE.

Kasmir. 2010. "Pengantar Manajemen Keuangan". Jakarta. Pranada Media

Keown, Arthur J, dkk. 2004. "Manajemen Keuangan, Prinsipprinsip dan Aplikasi”. Jakarta. Indeks

Kuncoro. 2009. "Metode Riset untuk Bisnis dan Ekonomi”. Jakarta. Erlangga.

Santosa dan Hamdani. 2007. "Statistika Deskriptif dalam Bidang Ekonomi dan Niaga". Jakarta. Erlangga.

Sjahrial Dermawan. 2007. "Manajemen Keuangan Lanjutan". Jakarta. Mitra Wacana Media

Sugiono, Arief. 2009. "Manajemen Keuangan untuk Praktisi Keuangan". Jakarta. Grasindo.

http://www.anneahira.com/distro.html

http://bisnisukm.com/bangkitkan-usaha-kecil-menengah-denganmemproduksi-boneka.html

http://www.bi.go.id.

http://www.depkop.go.id/index.php?option=com_content $\& v i e w=a$ rticle\&id=129

http://repository.usu.ac.id/bidstream/123456789/26560/5/Chapter \%201.pdf

http://www.waspada.co.id/index.php?option=com_content\&view= article \&id=247617:koperasi-dan-umkm-penting-bagiperekonomian \&catid=14: medan $\&$ Itemid $=27$ 